\section{BRAZIULIAN JOURNAL}

OF MEDICAL AND BIOLOGICAL RLSH.ARCH

www.bjournal.com.br
ISSN 0100-879X

Volume 43 (01) 1-123 January 2010

BIOMEDICAL SCIENCES

AND

CLINICAL INVESTIGATION

Braz J Med Biol Res, J anuary 2010, Volume 43(1) 13-16

Genetic analysis of the porcine group B rotavirus NSP2 gene from wild-type Brazilian strains

K.C. Médici, A.F. Barry, A.F. Alfieri and A.A. Alfieri

The Brazilian Journal of Medical and Biological Research is partially financed by
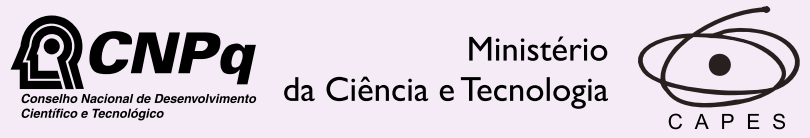

Ministério da Educação

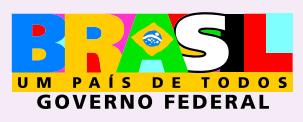

Institutional Sponsors 


\title{
Genetic analysis of the porcine group B rotavirus NSP2 gene from wild-type Brazilian strains
}

\author{
K.C. Médici, A.F. Barry, A.F. Alfieri and A.A. Alfieri \\ Laboratório de Virologia Animal, Departamento de Medicina Veterinária Preventiva, \\ Universidade Estadual de Londrina, Londrina, PR, Brasil
}

\begin{abstract}
Group B rotaviruses (RV-B) were first identified in piglet feces, being later associated with diarrhea in humans, cattle, lambs, and rats. In human beings, the virus was only described in China, India, and Bangladesh, especially infecting adults. Only a few studies concerning molecular analysis of the RV-B NSP2 gene have been conducted, and porcine RV-B has not been characterized. In the present study, three porcine wild-type RV-B strains from piglet stool samples collected from Brazilian pig herds were used for analysis. PAGE results were inconclusive for those samples, but specific amplicons of the RV-B NSP2 gene (segment 8) were obtained in a semi-nested PCR assay. The three porcine RV-B strains showed the highest nucleotide identity with the human WH1 strain and the alignments with other published sequences resulted in three groups of strains divided according to host species. The group of human strains showed 92.4 to $99.7 \%$ nucleotide identity while the porcine strains of the Brazilian RV-B group showed 90.4 to $91.8 \%$ identity to each other. The identity of the Brazilian porcine RV-B strains with outer sequences consisting of group $A$ and $C$ rotaviruses was only 35.3 to $38.8 \%$. A dendrogram was also constructed to group the strains into clusters according to host species: human, rat, and a distinct third cluster consisting exclusively of the Brazilian porcine RV-B strains. This is the first study of the porcine RV-B NSP2 gene that contributes to the partial characterization of this virus and demonstrates the relationship among RV-B strains from different host species.
\end{abstract}

Key words: Piglets; Diarrhea; Group B rotavirus; NSP2 gene; Phylogenetic analysis

\section{Introduction}

Rotavirus belongs to the Reoviridae family and consists of 11 segments of linear double-stranded RNA enclosed in a triple-layer capsid. Rotaviruses are classified into seven distinct serologic groups designated from $A$ to $G$ on the basis of the main protein (VP6) of the intermediary capsid layer (1). Group A rotaviruses (RV-A) are responsible for most of the cases of diarrhea in piglets. Non-RV-Aare rarely reported due to the difficulty in the diagnosis of diarrheas caused by other rotavirus groups (2).

Group B rotaviruses (RV-B) were first identified as the causative agents of enteric disease in pigs (3). RV-B are also associated with severe gastroenteritis in humans, cattle, sheep, goats, and rats (4). Although there is serological evidence that human RV-B, named adult diarrhea rotavirus (ADRV), is present in many countries, the virus has only been detected in China, India, and Bangladesh, where most cases occur in adults (5). After the first description of porcine RV-B in 1980, other studies showed the presence of the virus in feces of pigs and described the first isolation of porcine RV-B in cell culture (6). Serological studies using enzyme-linked immunosorbent assay (ELISA) in pig herds from the United Kingdom demonstrated antibody prevalence of $97 \%$, indicating that porcine RV-B infections are widespread (7).

Since RV-B particles are shed at low levels and isolation in tissue culture is rarely successful, the diagnosis of RV-B from human and pig fecal samples has been performed mainly by the direct detection of viral nucleic acid by polyacrylamide gel electrophoresis (PAGE) analysis or after amplification by RT-PCR assay (8).

The properties and functions of nonstructural protein 2 (NSP2 or NS35) of groupA rotaviruses have been described. NSP2 is a conserved basic protein expressed at high levels in infected cells. The protein is a polymer containing oc-

Correspondence: A.A. Alfieri, Laboratório de Virologia Animal, Departamento de Medicina Veterinária Preventiva, Universidade Estadual de Londrina, Campus Universitário, 86051-990 Londrina, PR, Brasil. Fax: +55-43-3371-4485. E-mail: alfieri@uel.br

Received April 14, 2009. Accepted December 7, 2009. Available online January 11, 2010. Published January 11, 2010. 
tamers and has $\mathrm{Mg}^{2+}$-dependent NTPase activity, which provides the energy necessary to direct the packaging of viral mRNA. NSP2 also has helix-destabilizing (helicaselike) activity and, through its interaction with NSP5, NSP2 is necessary for genomic replication (9).

Few studies involving molecular analysis of the NSP2 gene of RV-B have been conducted. Indeed, the available published analyses present contradictory results in the classification of human strains detected in China (ADRV) and India (CAL); however, a possible mistake in sequence analysis may have occurred in the first study $(10,11)$.

Despite the small number of RV-B sequences available, a pair of primers designed by Gouvea et al. (2) targeting the NSP2 gene was able to detect human and animal RV-B strains in fecal samples. The assay is a semi-nested (SN) PCR and may be used for RV-B screening since this non-structural protein gene is believed to conserve among RV-B strains. The present study describes the molecular characterization based on partial NSP2 gene sequencing of porcine RV-B strains detected in Brazil. In addition, phylogenetic analysis was performed on these porcine RV-B strains and other strains available in public databases from different host species.

\section{Material and Methods}

Five fecal samples with typical electropherotype patterns of RV-B in PAGE analysis and the expected 434-bp amplicon of the RV-B NSP2 gene (segment 8) in an agarose gel of SN-PCR were selected for molecular analysis. They were part of a collection of 588 piglet stool samples screened by PAGE for the presence of rotavirus. Three RV-B SN-PCR amplicons could be sequenced. Two were from 2-week-old non-diarrheic piglets (BRA12-UEL and BRA14-UEL) and one was from a 1-week-old diarrheic piglet (BRA16-UEL). The specimens were collected in 2005 from pig herds in the Southern region of Brazil [Paraná-PR (BRA12-UEL and BRA16-UEL) and Santa Catarina-SC (BRA14-UEL) States].

RNA was extracted from fecal specimens for SN-PCR by the method of Alfieri et al. (12) followed by RT-PCR with primers B1 (5'CTATTCAGTGTGTCGTGAGAGG3')/B4 (5'CGTGGCTTTGGAAAATTCTTG3') and SN-PCR with B1/B3 (5'CGAAGCGGGCTAGCTTGTCTGC3') (2). These three samples were negative for the presence of RV-A and RV-C by RT-PCR assay (13-15).

Amplicons were purified with GFX PCR DNA and with the Gel Band Purification Kit (GE Healthcare, UK) and quantified with the low DNA mass ladder (Invitrogen ${ }^{\mathrm{TM}}$ Life Technologies, USA). The sequences were obtained with the DYEnamic ET Dye Terminator Kit (GE Healthcare) in a MegaBACE 1000 sequencer using the same primers of SN-PCR in both directions. Sequence quality analysis was performed using the Phred and CAP3 software (http://genoma.cenargen.embrapa.br/phph/) and similarity searches were performed using the BLAST software (http:// www.ncbi.nlm.nih.gov/BLAST/). A multiple alignment and an identity matrix were produced with the BioEdit software version 7.0.5.3. A phylogenetic tree was constructed using the neighbor-joining algorithm based on the Kimura 2-parameter distance estimative method for nucleotides, providing statistical support with bootstrapping with 1000 replicates by the MEGA package (version 3.1). The sequences included in the study were available at the National Center for Biotechnology Information, USA (GenBank) (http://www.ncbi. nlm.nih.gov/GenBank/).

\section{Results and Discussion}

In BLAST analysis, the BRA12-UEL, BRA14-UEL, and BRA16-UEL sequences were more similar to the $\mathrm{WH} 1 \mathrm{hu}-$ man RV-B strain, which was detected in a sporadic case of adult diarrhea in Wuhan Hubei, China, in 2002 (16). Multiple alignment with other published sequences generated a 356-nucleotide fragment from the NSP2 gene, and resulted in three groups of strains divided according to host species: porcine, rat, and human. The major group, which consisted of the human strains, showed 92.4 to $99.7 \%$ identity, whereas the porcine group (which included only the Brazilian porcine RV-B wild-type strains) had 90.4 to $91.8 \%$ identity. When compared to outer group strains such as group $A$ (simian) and C (human) rotaviruses, the Brazilian porcine RV-B sequences demonstrated only 35.3 to $38.8 \%$ nucleotide identity (Table 1 ). This analysis could not be performed with group $A$ and $B$ porcine rotavirus strains since there is no gene sequence of NSP2 available in the public databases.

Despite the fact that the porcine RV-B sequences were obtained from two different Brazilian States (PR and SC), the relatively low identity ( 90.4 to $91.8 \%$ ) among them indicates that the porcine strains were more heterogeneous than the human strains (92.4 to $99.7 \%$ identity), even when comparing human isolates obtained in different countries such as China and India (92.4 to $93.5 \%$ identity; Table 1). Whether the nucleotide variability of porcine strains will be confirmed in strains from other countries remains to be determined. In amino acid analysis, this heterogeneity was not maintained, with 96.5 to $99.1 \%$ similarity in the porcine group and 93.9 to $100 \%$ similarity in the human group (Table 1). However, the phylogenetic tree was similar at both the nucleotide and amino acid levels, where the host species clusters were clearly separated.

In the dendrogram reconstruction, the human RV-B strains were all grouped in the same cluster, and were clearly segregated into Indian (CAL) and Chinese (ADRV and WH1) subclusters. These were separated from the one-strain group (formed by the rat strain - IDIR) and from the porcine strain (BRA12-UEL, BRA14-UEL, and BRA16UEL) cluster. Together, these Brazilian porcine RV-B strains formed a distinct third cluster, which was subdivided into two 
Table 1. Nucleotide (normal type) and amino acid (bold type) identity matrix of part (356 nucleotides and 116 amino acids) of the NSP2 gene among Brazilian and published sequences of group $A, B$, and $C$ rotaviruses.

\begin{tabular}{|c|c|c|c|c|c|c|c|c|c|c|c|c|c|c|c|}
\hline Strain & BRA12 & BRA14 & BRA16 & CAL-1 & CAL-6 & CAL-10 & CAL-14 & CAL-16 & CAL-28 & Bang373 & ADRV & WH1 & IDIR & SA11 & Bristol \\
\hline BRA12/UEL & ID & 0.991 & 0.965 & 0.715 & 0.715 & 0.706 & 0.706 & 0.715 & 0.715 & 0.715 & 0.698 & 0.715 & NA & 0.09 & 0.122 \\
\hline BRA14/UEL & 0.918 & ID & 0.974 & 0.724 & 0.724 & 0.715 & 0.715 & 0.724 & 0.724 & 0.724 & 0.706 & 0.724 & NA & 0.09 & 0.122 \\
\hline BRA16/UEL & 0.904 & 0.918 & ID & 0.741 & 0.741 & 0.732 & 0.732 & 0.741 & 0.741 & 0.741 & 0.724 & 0.741 & NA & 0.09 & 0.122 \\
\hline CAL-1 & 0.705 & 0.693 & 0.724 & ID & 0.974 & 0.991 & 0.991 & 1 & 1 & 1 & 0.965 & 0.982 & NA & 0.065 & 0.131 \\
\hline CAL-6 & 0.702 & 0.688 & 0.724 & 0.985 & ID & 0.965 & 0.965 & 0.974 & 0.974 & 0.974 & 0.939 & 0.956 & NA & 0.073 & 0.131 \\
\hline CAL-10 & 0.696 & 0.685 & 0.721 & 0.991 & 0.988 & ID & 0.982 & 0.991 & 0.991 & 0.991 & 0.956 & 0.974 & NA & 0.065 & 0.122 \\
\hline CAL-14 & 0.705 & 0.688 & 0.719 & 0.983 & 0.974 & 0.98 & ID & 0.991 & 0.991 & 0.991 & 0.956 & 0.974 & NA & 0.065 & 0.131 \\
\hline CAL-16 & 0.707 & 0.696 & 0.724 & 0.988 & 0.98 & 0.985 & 0.988 & ID & 1 & 1 & 0.965 & 0.982 & NA & 0.065 & 0.131 \\
\hline CAL-28 & 0.699 & 0.688 & 0.724 & 0.994 & 0.991 & 0.997 & 0.983 & 0.988 & ID & 1 & 0.965 & 0.982 & NA & 0.065 & 0.131 \\
\hline Bang373 & 0.707 & 0.696 & 0.727 & 0.991 & 0.983 & 0.988 & 0.991 & 0.997 & 0.991 & ID & 0.965 & 0.982 & NA & 0.065 & 0.131 \\
\hline ADRV & 0.724 & 0.702 & 0.735 & 0.932 & 0.924 & 0.929 & 0.929 & 0.935 & 0.932 & 0.938 & ID & 0.982 & NA & 0.065 & 0.122 \\
\hline WH1 & 0.73 & 0.707 & 0.741 & 0.932 & 0.924 & 0.929 & 0.929 & 0.935 & 0.932 & 0.938 & 0.988 & ID & NA & 0.065 & 0.131 \\
\hline IDIR & 0.707 & 0.693 & 0.699 & 0.806 & 0.806 & 0.808 & 0.803 & 0.806 & 0.811 & 0.806 & 0.8 & 0.8 & ID & NA & NA \\
\hline SA11 & 0.353 & 0.371 & 0.388 & 0.377 & 0.369 & 0.374 & 0.363 & 0.371 & 0.374 & 0.371 & 0.363 & 0.363 & 0.369 & ID & 0.344 \\
\hline Bristol & 0.357 & 0.357 & 0.368 & 0.395 & 0.387 & 0.398 & 0.395 & 0.395 & 0.395 & 0.395 & 0.373 & 0.371 & 0.382 & 0.55 & ID \\
\hline
\end{tabular}

$\mathrm{NA}=$ sequence not available.

subclusters. The first subcluster was composed of strains BRA12UEL (PR) and BRA14-UEL (SC) from 2-week-old piglets without diarrhea, and the second by one strain (BRA16-UEL - PR) from a 1-week-old piglet with diarrhea. The number of strains analyzed was limited in order to associate the age and clinical signs with the molecular characteristics of the infecting strain (Figure 1).

In previous molecular analyses of genes encoding nonstructural proteins from RV-B strains from different host species, the ADRV (human) and IDIR (rat) strains demonstrated 66.1 and $71.7 \%$ nucleotide identity in the NSP1 (segment 6) and NSP5 (segment 11) genes, respectively, whereas the gene sequence of the structural protein VP7 showed 48.6 to $61.5 \%$ identity (17-19). In the present study, the similarity of the human (ADRV) and rodent (IDIR) strains regarding the NSP2 gene was $80 \%$, revealing that this gene is conserved more than other nonstructural (NSP1 and NSP5) and structural (VP7) protein genes.

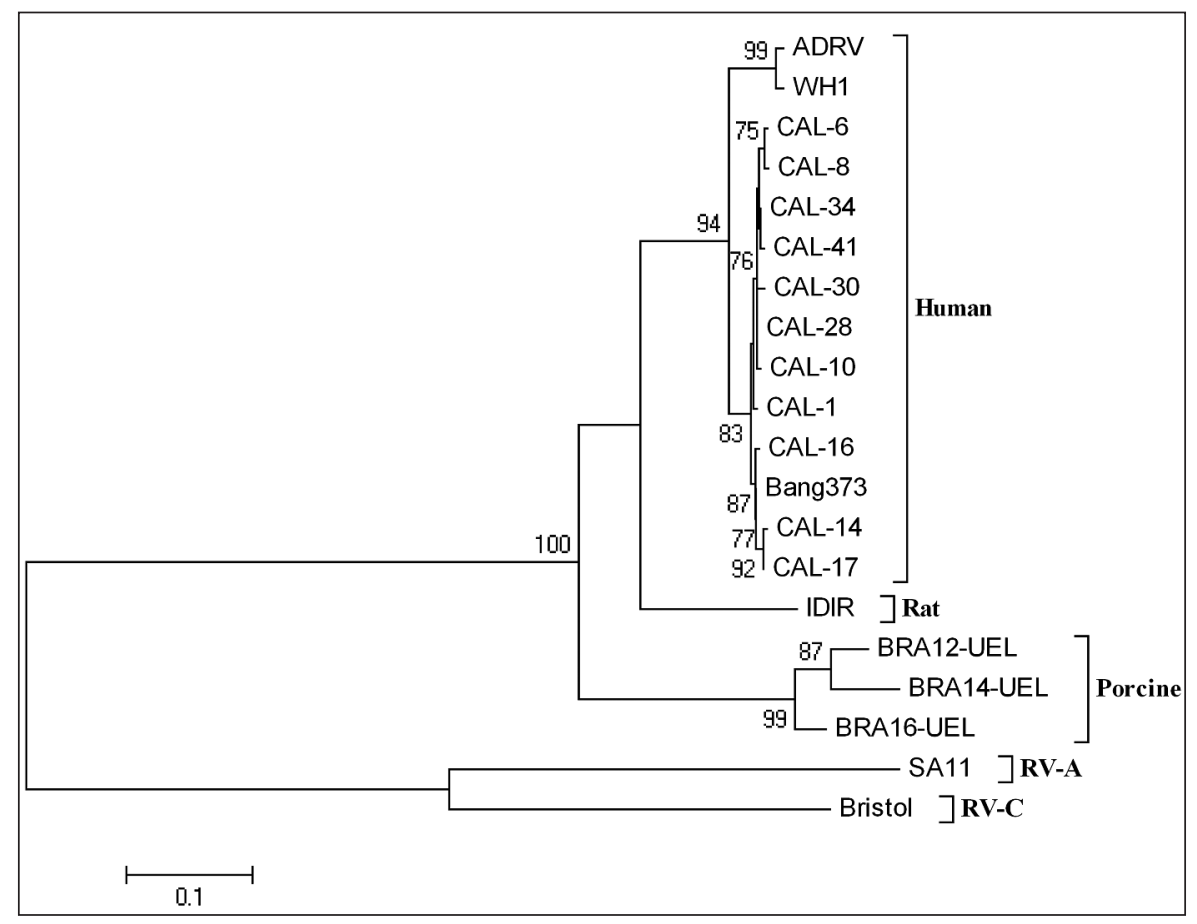

Figure 1. Phylogenetic tree between group B rotavirus human strains [CAL-1 (AY238383), CAL-6 (AY941792), CAL-8 (AY864913), CAL-10 (AY864914), CAL-14 (AY941778), CAL-16 (AY941789), CAL-17 (AY941776), CAL-28 (AY941777), CAL-30 (AY941790), CAL-34 (AY941791), CAL-41 (AY941779), Bang373 (AY238393), ADRV (AJ867609), and WH1 (AY212934)]; rat strain [IDIR (U03558)], and porcine strains [BRA12-UEL (EF577257), BRA14-UEL (EF577258), and BRA16UEL (EF577259)] based on part (356 nucleotides) of the NSP2 gene. The SA11 (DQ838615) primate group A rotavirus (RV-A) strain, and Bristol (AJ132205) human group C rotavirus (RV-C) strain were used as an outgroup. The tree was constructed as described in Material and Methods. 
In spite of this, the strains from different hosts (porcine, human, and rat) formed distinct groups in molecular and phylogenetic analyses, suggesting that the RV-B strains were well adapted to their hosts. Similar results for the VP6 gene were observed by Tsunemitsu et al. (20). This investigator suggested that the RV-B of different species may have had longer periods of time to diverge from one another than RV-A and RV-C. The molecular analyses of different rotavirus groups seem to be similar either in this structural protein gene (VP6) or in the NSP2 gene, in which RV-A and RV-C are related more closely to each other than RV-B.

To our knowledge, this is the first report of the phylogenetic analysis of the NSP2 gene from porcine RV-B strains. Thus, no other porcine strain was available for comparison. Before the present study, few molecular studies of RV-B

\section{References}

1. ICTVdB. The universal virus database. [Computer program]. Version 4. http://www.ncbi.nlm.nih.gov/lCTVdb/. 2009.

2. Gouvea V, Allen JR, Glass RI, Fang ZY, Bremont M, Cohen $\mathrm{J}$, et al. Detection of group B and C rotaviruses by polymerase chain reaction. J Clin Microbiol 1991; 29: 519-523.

3. Pedley S, Bridger JC, Brown JF, McCrae MA. Molecular characterization of rotaviruses with distinct group antigens. J Gen Virol 1983; 64 (Part 10): 2093-2101.

4. Snodgrass DR, Herring AJ, Campbell I, Inglis JM, Hargreaves FD. Comparison of atypical rotaviruses from calves, piglets, lambs and man. J Gen Virol 1984; 65 (Part 5): 909914.

5. Sanekata T, Ahmed MU, Kader A, Taniguchi K, Kobayashi N. Human group $B$ rotavirus infections cause severe diarrhea in children and adults in Bangladesh. $J$ Clin Microbiol 2003; 41: 2187-2190.

6. Sanekata T, Kuwamoto Y, Akamatsu S, Sakon N, Oseto M, Taniguchi $\mathrm{K}$, et al. Isolation of group B porcine rotavirus in cell culture. J Clin Microbiol 1996; 34: 759-761.

7. Brown DW, Beards GM, Chen GM, Flewett TH. Prevalence of antibody to group B (atypical) rotavirus in humans and animals. J Clin Microbiol 1987; 25: 316-319.

8. Bridger JC. Non-group A rotaviruses. In: Kapikian AZ (Editor), Viral infection of the gastrointestinal tract. 2nd edn. New York: Marcel Dekker; 1994. p 369-408.

9. Taraporewala ZF, Patton JT. Identification and characterization of the helix-destabilizing activity of rotavirus nonstructural protein NSP2. J Virol 2001; 75: 4519-4527.

10. Sen A, Kobayashi N, Das S, Krishnan T, Bhattacharya SK, Naik TN. The evolution of human group B rotaviruses. Lancet 2001; 357: 198-199.

11. Jiang B, Wang Y, Glass RI, Fang ZY. The evolution of human group B rotaviruses: correction and an update. J Clin Virol 2005; 34: 158-159.

12. Alfieri AA, Parazzi ME, Takiuchi E, Medici KC, Alfieri AF. Frequency of group A rotavirus in diarrhoeic calves in Brazilian were conducted even in other host species. The present results contribute to the characterization of porcine RV-B by demonstrating the relationship among RV-B from different host species. Further studies are needed to characterize and classify other circulating RV-B strains, including porcine strains from other countries, in order to determine whether this genetic variability also occurs among strains from distinct geographical areas.

\section{Acknowledgments}

We would like to thank the Brazilian Agencies CNPq, CAPES, FINEP, and Fundação Araucária for financial support. A.A. Alfieri and A.F. Alfieri are recipients of CNPq fellowships. cattle herds, 1998-2002. Trop Anim Health Prod 2006; 38: 521-526.

13. Gouvea V, Glass RI, Woods P, Taniguchi K, Clark HF, Forrester $\mathrm{B}$, et al. Polymerase chain reaction amplification and typing of rotavirus nucleic acid from stool specimens. J Clin Microbiol 1990; 28: 276-282.

14. Gentsch JR, Glass RI, Woods P, Gouvea V, Gorziglia M, Flores J, et al. Identification of group A rotavirus gene 4 types by polymerase chain reaction. J Clin Microbiol 1992; 30: 1365-1373.

15. Alfieri AA, Leite JP, Alfieri AF, Jiang B, Glass RI, Gentsch $J R$. Detection of field isolates of human and animal group $C$ rotavirus by reverse transcription-polymerase chain reaction and digoxigenin-labeled oligonucleotide probes. $J$ Virol Methods 1999; 83: 35-43.

16. Yang JH, Kobayashi N, Wang YH, Zhou X, Li Y, Zhou DJ, et al. Phylogenetic analysis of a human group $B$ rotavirus $\mathrm{WH}-1$ detected in China in 2002. J Med Virol 2004; 74: 662-667.

17. Chang KO, Parwani AV, Smith D, Saif LJ. Detection of group $B$ rotaviruses in fecal samples from diarrheic calves and adult cows and characterization of their VP7 genes. J Clin Microbiol 1997; 35: 2107-2110.

18. Shen S, McKee TA, Wang ZD, Desselberger U, Liu DX. Sequence analysis and in vitro expression of genes 6 and 11 of an ovine group $B$ rotavirus isolate, KB63: evidence for a non-defective, C-terminally truncated NSP1 and a phosphorylated NSP5. J Gen Virol 1999; 80 (Part 8): 2077-2085.

19. Barman P, Ghosh S, Das S, Varghese V, Chaudhuri S, Sarkar S, et al. Sequencing and sequence analysis of VP7 and NSP5 genes reveal emergence of a new genotype of bovine group B rotaviruses in India. J Clin Microbiol 2004; 42: 2816-2818.

20. Tsunemitsu H, Kamiyama M, Kawashima K, Katsuda K, Kohmoto M, Saif LJ, et al. Molecular characterization of the major capsid protein VP6 of bovine group B rotavirus and its use in seroepidemiology. J Gen Virol 2005; 86: 2569-2575. 